\title{
Phytotoxicity of sediment from Gölcük Lake (İzmir, Turkey) on Desmodesmus (=Scenedesmus) dimorphus
}

\section{Gölcük Gölü (İzmir, Türkiye) sedimentinin Desmodesmus (=Scenedesmus) dimorphus üzerine fitotoksistesi}

\section{Meltem Boyacıoğlu* (iD • Hatice Parlak • Özlem Çakal Arslan • Muhammet Ali Karaaslan • Serkan Tez • Gizem Gülsever • Beyza Nalbantlar}

Faculty of Fisheries, Ege University, 35100 Bornova, İzmir, Turkey

Corresponding author: meltem.boyacioglu@ege.edu.tr

How to cite this paper:

Boyacıoğlu, M., Parlak, H., Çakalarslan, Ö. Karaaslan, M.A. Tez, S., Gülsever, G. \& Nalbantlar, B. (2017). Phytotoxicity of sediment from Gölcük Lake (Izmir, Turkey) on Desmodesmus (=Scenedesmus) dimorphus. Ege Journal of Fisheries and Aquatic Sciences, 34(2): 145-150. doi:10.12714/egejfas.2017.34.2.05

\begin{abstract}
Gölcük Lake (Bozdağ-Izmir) is polluted by the touristic activities and agricultural and domestic sources. Gölcük Lake also adversely impacts human health as the lake water is used for irrigation in agriculture, and the fish caught from the lake is used for nutrition by the community around it. For this purpose, "OECD 201 Algal Growth Inhibition Test", the standard test protocol was evaluated with cultures of green algae Desmodesmus dimorphus as the representative of the first trophic level. This test was used to assess the toxicity of sediment samples collected from five sampling sites in Gölcük Lake. Extracts of sediment samples were assayed in four different concentrations $(20,40,100$, and $200 \mathrm{mg} / \mathrm{ml})$. The effects on the growth of $D$. dimorphus were examined by scoring cell numbers under the light microscope with a Neubauer haemocytometer counting chamber. According to the results, all extracts, except those from Station 3 , inhibited growth of $D$. dimorphus in increasing concentrations of sediment samples, and inhibition was observed in the following order of stations: $2>5>4>1$. Additionally, an increase in the number of algae (hormesis) was observed in the Station 3, depending on time and concentrations.
\end{abstract}

Keywords: Algal Growth Inhibition Test, Pollution, Freshwater, Gölcük Lake

Öz: Gölcük Gölü (Bozdağ-lzmir) turizm aktiviteleri, evsel ve tarımsal kaynaklar nedeniyle kirlenmektedir. Gölcük Gölü’nün suyu tarımda sulama amaçlı kullanılmakta ve gölden beslenme amacıyla balık avlandığı için göl suyu, civarındaki halkın sağı̆̆ııı da olumsuz yönde etkilemektedir. Bu amaçla, "OECD 201 Algal Büyüme İnhibisyon Testi" kısa zamanlı phytotoxicity test yöntemi için standart bir test protokolüdür ve yeşil alglerden olan Desmodesmus dimorphus kültürü birinci trofik seviye temsilcisi olarak değerlendirilmektedir. Bu test, gölden daha önceden belirlenmiş 5 örnekleme yerinden toplanan sediment örneklerinin toksisitesini değerlendirmek için kullanıldı. Sediment örneklerinin ekstraktları dört farklı konsantrasyonda $(20,40,100$ ve $200 \mathrm{mg} / \mathrm{ml}$ ) test edildiler. Desmodesmus dimorphus'un büyümesi üzerindeki etkiler, sayma kamarası Neubauer hemositometre ile ışık mikroskopu altında hücre sayımı yapılarak değerlendirilmiştir. Sonuçlara göre, 3 numaralı istasyon dışında tüm sediment ekstraktları artan konsantrasyona bağlı olarak Desmodesmus dimorphus büyümesini engellemiştir ve bu istasyonlar sırasıyla $2>5>4>1$ nolu istasyonlardır. Ayrıca 3 nolu istasyonda zamana ve konsantrasyona bağlı olarak alg sayısında artış (hormesis) gözlenmiş̧tir.

Anahtar kelimeler: Algal Büyüme İnhibisyon Testi, Kirlilik, Tatlısu, Gölcük Gölü

\section{INTRODUCTION}

Gölcük Lake is one of the most important lakes of western part of Turkey because of its tourism potential and the scenic beauty of the region. It can also be classified as an eutrophic lake, with its altitude of $1050 \mathrm{~m}$ and covers area of $0.81 \mathrm{~km}^{2}$ (Yıldız et al., 2015). The increase in population, urbanization, campgrounds, pesticides used in agricultural activities, detergents, and various chemicals released as domestic wastes nearby the lake lead to a significant increase of the pollution in Gölcük Lake. The lake also affects human health as the lake water is used in irrigation in agriculture, and the fish caught from the lake is used for nutrition by the community. The pollutants are thought to be pesticides, polycyclic aromatic hydrocarbons (PAH), and domestic wastes. Mutagens and carcinogens originated from the industrial and agricultural activities reach to the lakes and the seas through the terrestrial drainage and rivers. De Flora et al. (1991) reported and underlined the significant increase in the amount of tumorous fish and stated that the increase might have been caused by pollution, which was brought along carcinogenic and mutagenic xenobiotics in the environment. Moreover, determination of the chemical compounds of the sediment, which stores all of the pollutants in the aquatic environment, and its effects on the 
aquatic organisms have gained importance in the ecotoxicological studies. It was shown by Furlong et al. (1988) that many chemicals discharged were hydrophobic in nature. These chemicals might resist degradation by the bacteria and tended to reach high levels in the sediment or biota (Furlong et al., 1988; Alexander 1981).

Currently, aquatic toxicity tests are routinely utilized in practice to assess the risks related to discharge of the effluents into the water bodies and sediments (Üstün, 2011). Despite the fact that the analytical chemical assays give information on quality and quantity of the pollution, biological assays can describe presence and strength of the toxicity qualitatively (Feiler et al., 2006). The organisms from all trophic levels living in the aquatic environments are used in ecotoxicological assays of pollution in the aquatic systems and sediments (Ratushnyak, 2007). The algae were reported to be equal to or even more suspectible than animals (Ferreira and Graca, 2002) and they have been widely used in the toxicity assays. In the present investigation, the potential toxicity of sediments from Gölcük Lake was tested by using the algal (Desmodesmus dimorphus) growth inhibition test, evaluating the information above. The present study aimed at interpreting ecotoxicological situation of the lake, determining toxicity of the sediment. Monitoring effects of the pollution is important since it indicates whether the ecosystem is appropriate for the organisms. Although there are few studies reporting on characterization of Gölcük Lake, living material, phytoplanktonic and zooplanktonic organisms, bentic microoganisms, physicochemical parameters of Gölcük Lake (Yıldız et al., 2015; Geldiay and Tareen 1972; Uysal et al.,1985; Kınacıgil, 1985; Uysal et al., 1987; Toksöz and Ustaoğlu, 2005; Özdemir Mis and Ustaoğlu, 2009), there are no studies reporting on charecterisation of sediment toxicity.

\section{MATERIALS AND METHODS}

Sediment samples were collected from 5 stations located in Gölcük Lake (Figure 1) in June 2008, and the stations depths were measured as 2,3 $\mathrm{m}$ for station $1 ; 3,2 \mathrm{~m}$ for station $2 ; 4 \mathrm{~m}$ for station 3-4; and 2,9 $\mathrm{m}$ for station 5 . Sediment samples were collected by using the grab sampler and kept in an ice-box until being transferred to the laboratory and then stored in a freezer at $-20^{\circ} \mathrm{C}$ until the phytotoxicity tests.

Extractions of the sediment samples: Samples were airdried at room temperature and then were crushed to powder and sifted in the laboratory. Then placed in portions of $1 \mathrm{~g}$ into teflon tubes and mixed with $1 \mathrm{ml}$ hexane/chloroform/acetone (1:1:1, v: v: v) using a vortex mixer (Kotelevtsev and Stepanova, 1995). Subsequently, the samples were centrifuged for 10 minutes at $+4^{\circ} \mathrm{C}$ at $5600 \mathrm{~g}$ (Sigma K3) and then the supernatants were transferred into the tubes. This procedure was repeated three times and pooled. Supernatants were evaporated and then dissolved by adding $1 \mathrm{ml}$ of dimethylsulfoxide (DMSO) (Kotelevtsev and Stepanova, 1995). The extracts of sediment samples were assayed in concentrations of $20,40,100,200 \mathrm{mg} / \mathrm{ml}$ and the control test series, containing a negative control group that included only the prepared test medium, and a positive control group which were exposed to $\mathrm{K}_{2} \mathrm{CrO}_{4}$. All test series were replicated three times (Figure 1).

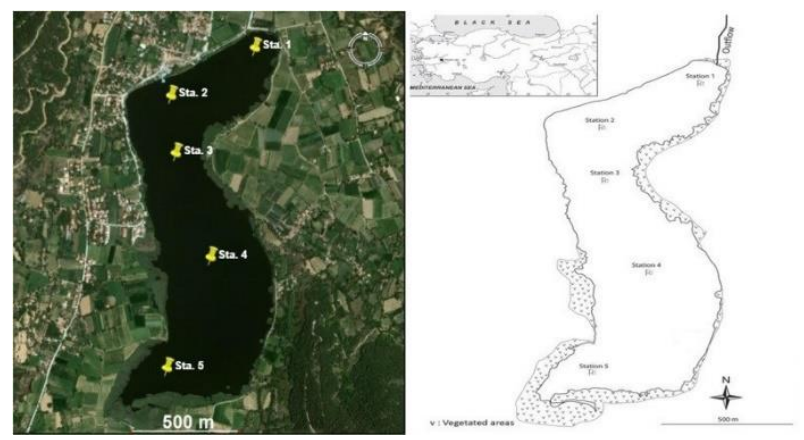

Figure 1. Location of Gölcük Lake and the sampling stations (Yıldız et al., 2015)

The algal growth inhibition test was performed by using the green alg Desmodesmus dimorphus (Turpin) Kützing 1834. The algae were cultured on an OECD 201 algal medium. This bioassay was done according to the standard procedure of OECD 201 (OECD, 2011; Katalay et al., 2012). Three days prior to the bioassay, a pre-culture was set up and incubated at $21 \pm 2^{\circ} \mathrm{C}$. The initial cell concentration in the test cultures was approximately $2-5 \times 10^{3}$ cells $/ \mathrm{ml}$ for $D$. dimorphus. Test tubes were held on a shaker at $100 \mathrm{rpm}$ under constant lighting at approximately 2000 lux. The relative inhibition of growth rate was determined as the reduced cell number of the treated samples relative to the controls. Cell density was confirmed at every time point $(24,48$, and 72 hours) using the Neubauer haemocytometer counting chamber, and the $\mathrm{pH}$ of the cultures were measured to check whether the $\mathrm{pH}$ values showed remarkable difference between the initially measured values. The endpoints were evaluated based on cell count data, and growth rate was calculated ( 0 to $72 \mathrm{~h}$ ) as described in the standard protocols from the mean cell counts of each test series. The average specific growth rate $(\mu)$ for exponentially growing cultures was calculated as:

$$
\begin{aligned}
& \mu_{0-j}=\ln x_{j}-\ln x_{0} / t_{j}-t_{0}(\text { day- } 1) \\
& \mu_{0-j}: \text { growth rate, } \\
& x_{0}: \text { nominal number of cells } / \mathrm{ml} \text { at time } t_{0}, \\
& x_{j}: \text { measured number of cells } / \mathrm{ml} \text { at } t_{j},
\end{aligned}
$$

tj: time to the first measurement after beginning of the test.

The percentage of inhibition of the cell growth (Ir\%) for each concentration of the test substances was calculated as the difference between the control growth curve $\left(\mu_{\mathrm{c}}\right)$ and the growth curve at each concentration of the test substance $\left(\mu_{\mathrm{t}}\right)$ as: Ir $\%=$ $\mu_{\mathrm{c}}-\mu_{\mathrm{r}} / \mu_{\mathrm{c}} \times 100$.

$E_{50}$ values were calculated from the inhibitionconcentration curve as $50 \%$ growth inhibition of the test population compared to the control treatment, based on growth rate, by using a non-linear regression analysis (OECD, 2011). 
The data of growth rates were compared with controls by a $t$ test. Statistical analysis was performed as Hocking (1996) described, and the software Statistica 6.0 was used.

\section{RESULTS}

Results of the phytotoxicity test performed using the sediment samples from Gölcük Lake were considered to show a toxic effect (inhibition percentage) on growth rate $(\mu)$ of $D$. dimorphus (Figure 2). The bioassay with $D$. dimorphus by using the calculated inhibition percentage showed that the concentrations added (20, 40, 100 and $200 \mathrm{mg} / \mathrm{ml})$ from all stations of Gölcük Lake caused a reduction in cell numbers relative to the controls (Table 1). The inhibition percentage of sediment concentrations (Figure 2) and growth rates for each station are shown in (Figure 1). The $\mathrm{EC}_{50}$ values of the sediments were calculated from the inhibition percentage of the growth rates. The significant inhibition of growth was found for the each amount of sediment from all stations ranging from 2.6$5.7 \mathrm{mg} / \mathrm{ml}$ (Table 2). An increase in the number of the algae (hormesis) was observed in the sta. 3, depending on time and various concentrations. The sediment samples from the other stations 2, 5, 1, and 4 caused a decrease of 50 percent of the population. When all data were compared to the control group, significant inhibitions were observed $(p<0.005)$. The $E_{50}$ values $(\mathrm{mg} / \mathrm{ml})$ were calculated as shown in Figure 4 . Toxicity was found in the following order: stations $2>5>4>1$ in the exponential phase of growth (72h).

In general, sediment extracts of toxicity increased with increasing concentrations. In a bioassay with $D$. dimorphus, inhibiting effect of the sediment extracts increased from 24 to 72 hours of exposure. The most prominent negative effect of the sediment on the algae was observed at sta. 3 (Table 2, Figure 2). All cells in positive control group were observed to be dead at the $24^{\text {th }}$ hour of the experiment.

Table 1. Growth rates of $D$. dimorphus exposed to sediment extracts and inhibition percentage of the growth rate at exposure periods of 24 , 48 , and $72 \mathrm{~h}$.

\begin{tabular}{|c|c|c|c|c|c|c|}
\hline \multirow[t]{2}{*}{$\begin{array}{l}\text { Amount of sediment } \\
(\mathrm{mg} / \mathrm{ml})\end{array}$} & \multicolumn{3}{|c|}{ Growth Rate (day ${ }^{-1}$ ) } & \multicolumn{3}{|c|}{ Inhibition \% } \\
\hline & $24 \mathrm{~h}$ & $48 \mathrm{~h}$ & $72 \mathrm{~h}$ & $24 \mathrm{~h}$ & $48 \mathrm{~h}$ & $72 \mathrm{~h}$ \\
\hline \multicolumn{7}{|l|}{ Station 1} \\
\hline Control & 0.74 & 0.62 & 0.81 & & & \\
\hline 20 & 0.27 & 0.21 & 0.67 & 66.56 & 73.91 & $17.44^{*}$ \\
\hline 40 & 0.11 & 0.18 & 0.68 & 87.07 & 77.26 & $16.63^{*}$ \\
\hline 100 & 0.04 & 0.40 & 0.65 & 95.68 & 50.61 & $19.52^{*}$ \\
\hline 200 & 0.00 & 0.05 & 0.46 & 100.00 & 93.68 & $43.13^{*}$ \\
\hline \multicolumn{7}{|l|}{ Station 2} \\
\hline Control & 0.74 & 0.62 & 0.81 & & & \\
\hline 20 & 0.08 & 0.44 & 0.87 & 90.54 & 45.88 & $-6.94^{*}$ \\
\hline 40 & -0.08 & 0.31 & 0.77 & 110.31 & 62.11 & $4.93^{*}$ \\
\hline 100 & -0.14 & -0.22 & 0.21 & 116.63 & 126.94 & $73.91^{*}$ \\
\hline \multicolumn{7}{|l|}{ Station 3} \\
\hline Control & 0.74 & 0.62 & 0.81 & & & \\
\hline 20 & 0.02 & 0.47 & 0.80 & 97.78 & 42.00 & $1.63^{*}$ \\
\hline 40 & 0.16 & 0.40 & 0.84 & 80.72 & 50.61 & $-3.68^{*}$ \\
\hline \multicolumn{7}{|l|}{ Station 4} \\
\hline Control & 0.74 & 0.62 & 0.81 & & & \\
\hline 20 & 0.08 & 0.46 & 0.95 & 89.94 & 43.13 & $-17.29^{*}$ \\
\hline 40 & -0.06 & 0.43 & 0.84 & 107.48 & 47.53 & $-3.19^{*}$ \\
\hline \multicolumn{7}{|l|}{ Station 5} \\
\hline Control & 0.74 & 0.62 & 0.81 & & & \\
\hline 20 & 0.07 & 0.41 & 0.79 & 91.77 & 49.26 & $2.18^{*}$ \\
\hline 40 & -0.01 & 0.42 & 0.76 & 101.55 & 48.39 & $6.15^{\star}$ \\
\hline 100 & -0.07 & 0.08 & 0.07 & 108.40 & 89.94 & $91.77^{*}$ \\
\hline
\end{tabular}




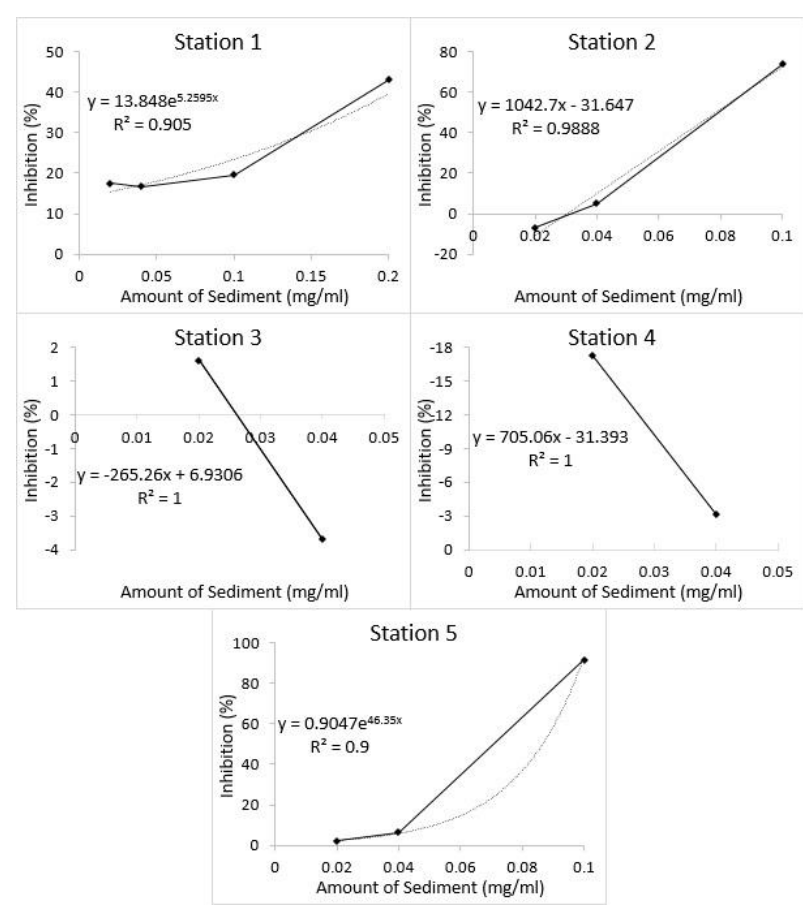

Figure 2. Inhibition percentage of the sediment extracts from Gölcük Lake on the growth rate of $D$. dimorphus at $72 \mathrm{~h}$ exposure period.

Table 2. $\mathrm{EC}_{50}$ values $(\mathrm{mg} / \mathrm{ml})$ and $\mathrm{EC}_{50}(\%)$ of the sediment extracts of the stations from Gölcük Lake.

\begin{tabular}{llc}
\hline Station numbers & $\mathrm{EC}_{50}(\%)$ & $\mathrm{EC}_{50}(\mathrm{mg} / \mathrm{ml})$ \\
\hline 1 & 61.13 & 5.31 \\
2 & 19.57 & 2.64 \\
3 & -40.59 & -8.11 \\
4 & 28.86 & 5.77 \\
5 & 21.64 & 2.82 \\
\hline
\end{tabular}

\section{DISCUSSION}

In this study, effects of the sediments from Gölcük Lake on the growth of algae Desmodesmus dimorphus were determined by exposing the algae to various concentrations of sediment extracts. Results of the algal tests showed that all sediment extracts, except those from one station inhibited growth of $D$. dimorphus at increasing concentrations of sediment samples. The highest inhibitions of growth rate of $D$. dimorphus exposed to sediment extracts were respectively founded at the stations $2>5>4>1$. Besides, an increase in the number of the algae (hormesis) was observed in the sta. 3 , depending on time and various concentrations. Pollution in the lake has been considered to be of anthropogenic origin and due to pesticides originated from touristic and agricultural activities because there are no signs of heavy metal pollution as there are no

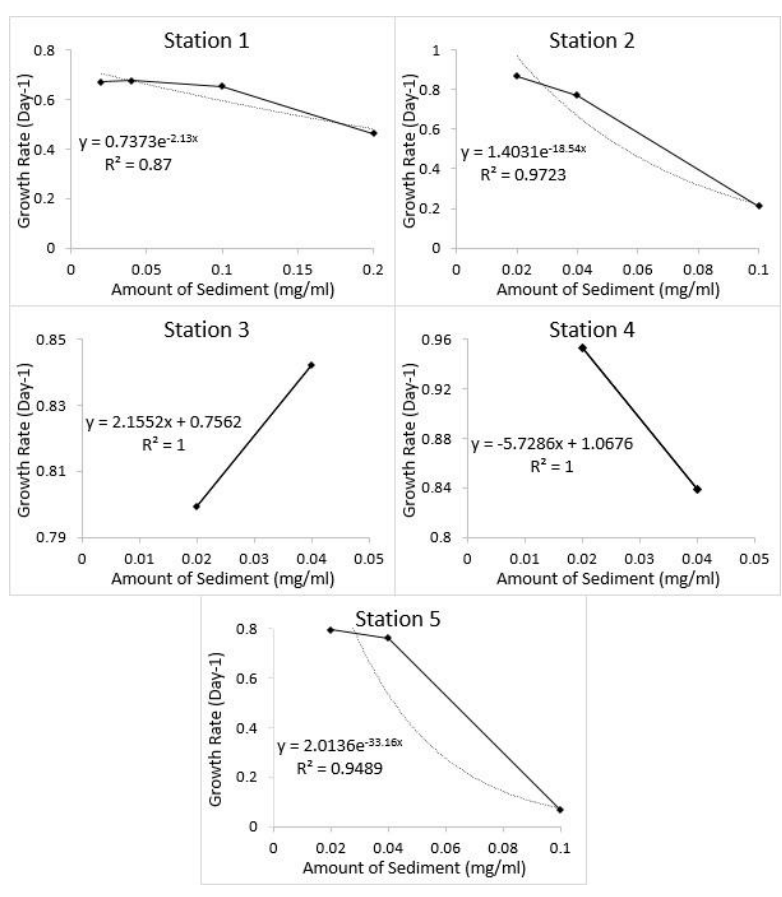

Figure 3. Growth rate of $D$. dimorphus exposed to sediment $(20,40$, $100,200 \mathrm{mg} / \mathrm{ml}$ ) of Gölcük Lake at $72 \mathrm{~h}$

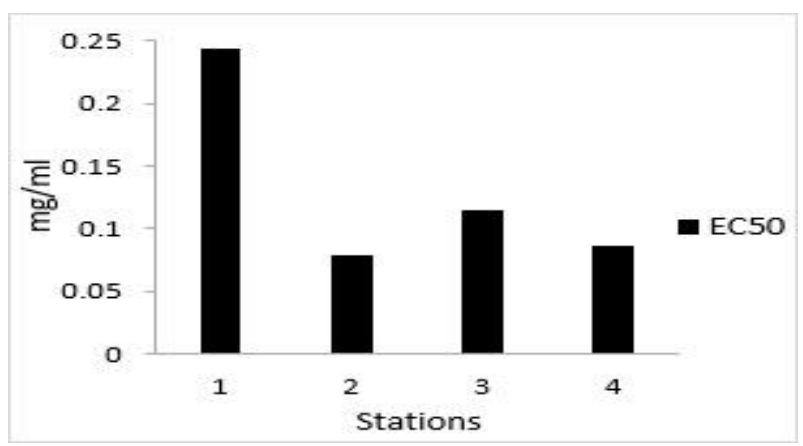

Figure 4. $\mathrm{EC}_{50}$ values of sediment samples from Gölcük Lake for stations.

industrial plants nearby the lake. Besides, the lake appeared in the news which was about how the lake became a landfill as there wasn't a waste water treatment plant for the sewage system of the zone (Yapar, 2015).

Bioassays are typically conducted to measure the effects of a substance on a living organism and are essential in the development of new drugs and in monitoring environmental pollutants. Phytotoxicity has become one of the most widely used biological toxicity tests. $D$. dimorphus algae which largely distribute in fresh waters are good species for biological toxicity tests (Sadiq et al., 2011). In addition, Pendashte et al., (2013) employed Chlorella vulgaris and $D$. dimorphus algae species in their study "toxicity of zinc oxide nanoparticles". It is well-known that phytotoxicity tests are appropriate for determining the adverse effects of various chemicals causing pollution in the 
environment. Besides, another phytotoxicity assay on Nif Brook was performed by Katalay et al. (2012) and the standard test protocol test method OECD 201. Algal Growth Inhibition has been evaluated with cultures of green algae Desmodesmus (=Scenedesmus) subspicatus as the representative of the first trophic level. The test was used to assess the toxicity of both water and sediment samples from the Nif Brook (Katalay et al., 2012).

In our study, the sediment extracs were tested for their potential adverse effect on the growth of $D$. dimorphus. The results revealed that the parameter of inhibition percentage in the growth rate of $D$. dimorphus presented a problem on the pollution of Gölcük Lake. Our results showed that contaminated sediments caused an inhibition of the growth rate of green freshwater alga $D$. dimorphus. Therefore, this method may be reliable for the determination of the pollution effects of Gölcük Lake sediments. Thus, the results show that the sediment of Gölcük Lake is polluted with toxic substances originated from touristic and agricultural activities in addition to the domestic wastes. Evidence of hormesis was observed for station 3. In an ecosystem study that investigated the same stations in the lake, it was noted that the stations 2 and 3 had intensely contained benthic species with high eutrophication tolerance such as Potamothrix hammoniensis, Tubifex tubifex, Chironomus plumosus, Chaoborus flavicans, and Ceratopogonidae larvae (Yıldı et al., 2015). Therefore, it explains that reason for the intensive reproduction of test algae exposed to sediment extracts of sta. 3 is that there are no toxic effects; moreover, nutrient intake level is high. Toxic effect was found to be higher for the sta. 2 than the other stations. Yıldız et al. (2015) pointed

\section{REFERENCES}

Alexander, M. (1981). Biodegradation of chemicals of environmental concern Science, 211(4478), 132-138. doi: 10.1126/science.7444456

Balık, S. \& Ustaoğlu, R. (1987). Gölcük Gölü'ndeki (Bozdağ- Ödemiş) sazan (Cyprinus carpio L.1758) populasyonunun biyolojik özellikleri üzerine araştırmalar (In Turkish with English abstract). VIII. Ulusal Biyoloji Kongresi, 1986 (Cilt 2, sayfa 656-671) İzmir, Kongre Bildiri Kitabı.

De Flora, S., Bagnasco, M. \& Zanacchi, P. (1991). Genotoxic, carcinoenic hazards in the marine environmental, with special reference to the Mediterranean Sea. Mutation Research/Reviews in Genetic Toxicology, 258(3), 285-320. doi: 10.1016/0165-1110(91)90013-L

Feiler, U., Krebs, F. \& Heininger, P. (2006). Aquatic plant assay used in the assessment of water quality in German rivers. Hydrobiologia 570: 67-71. doi: 10.1007/s10750-006-0163-7

Ferreira, R.C.F. \& Graca, M.A.S. (2002). A comparative study of the sensivity of selected aquatic plants to mining effluents. Limnetica 21 (1-2): 129-134.

Furlong, E. T., Carter, D. S., \& Hites, R. A. (1988). Organic contaminants in sediments from the Trenton Channel of the Detroit River, Michigan. Journal of Great Lakes research, 14(4), 489-501. doi: $10.1016 / \mathrm{S} 0380-1330(88) 71581-6$

Geldiay, R. \& Tareen, I.U. (1972). Preliminary survey of Gölcük, a eutrophic mountain lake in Western Turkey. Scientific Reports of Faculty of Science, Ege University, Bornova. No: 138.

Hocking, R.R. (1996). Methods and applications of linear models. Regression and the analysis of variance. New York: Wiley.

Katalay, S., Boyacıoğlu, M., Çakal Arslan, Ö., Parlak, H. \& Karaaslan, M.A (2012). Phytotoxicity of water and sediment from Nif Brook (İzmir, Turkey) out that the community structure of the lake has changed to a form containing the species with higher tolerance to pollution, and the lake is directly affected by the human activity around. The lake is used as a reservoir for irrigation in agricultural activities in the region. It has been polluted for years through terrestrial drainage and rain that transports the pesiticides and all other organic and inorganic pollutants used in those activities. In consequenses of, this gets the process into a cycle as the polluted water is re-used for irrigation.

Besides the usage of the lake in agriculture, it has also been stated that some fish species (Cyrinus carpio, Silurus glanis, Leuciscus cephalus, Leuciscus borysthenicus, Cobitis taenia) have important role in nutrition of the people in the region (Balık and Ustaoğlu, 1987). It is also known that domestic wastes are discharged from cafes, summerhouses, and hotels without a treatment since there is no wastewater treatment system around.

In this study, toxicants were found to be at hazardous levels for sediment of Gölcük Lake by using Percentage of Inhibition test with green algae $D$. dimorphus. Furthermore, it is necessary to perform analyses on the heavy metals, nitrogen, and phosphorus compounds to make toxicity and genotoxicity tests involving the local species of the lake and to determine pollution levels broadly.

\section{ACKNOWLEDGEMENTS}

This study was conducted in the context of the Scientific Research Project of Ege University (Project No: Project No:2008/SUF/06).

on green algae Desmodesmus (= Scenedesmus) subspicatus. Ekoloji, 21(83), 25-31. doi: 10.5053/ekoloji.2012.833

Kınacıgil, T. (1985). Gölmarmara ve Gölcük gölleri kerevitlerindeki (Actacus leptodactylus salinus Nordman, 1842) ağır metal birikimleri (In Turkish with English abstract). Ege Üniversitesi Su Ürünleri Yüksek Okulu (Yüksek Lisans Tezi), $20 \mathrm{~s}$.

Kotelevtsev, S.V. \& Stepanova, L.I. (1995). Biochemical and genotoxicological monitoring of ecosystems with special reference to Lake Baikal and Northern Black Sea. In E. Arınç, J.B. Schenkman \& E. Hodgson (Eds), Molecular aspects of oxidative drug metabolizing enzymes (pp. 567-589). Springer Berlin Heidelberg. doi: 10.1007/978-3-642-79528-2_28

OECD. (2011). Test No. 201: Freshwater alga and cyanobacteria, growth inhibition test, OECD Publishing, Paris.

Özdemir Mis. D., \& Ustaoglu, M.R. (2009). Gölcük Gölü (Ödemiş-İzmir)'nün zooplanktonu üzerine araştırmalar (In Turkish with English abstract). Ege Jornal of Fisheries and Aquatşc Sciences 26(1): 19-27.

Pendashte, H., Shariati, F., Keshavarz, A. \& Ramzanpour, Z. (2013). Toxicity of zinc oxide nanoparticles to Chlorella vulgaris and Scenedesmus dimorphus algae species. World Journal of Fish and Marine Sciences, 5(5), 563-570.

Ratushnyak, A. (2007). The role of microflora and plant supplements in Daphnia magna resistance to a toxicant. Ekoloji 16 (64): 77-80.

Sadiq, I.M., Pakrashi, S., Chandrasekaran, N. \& Mukherjee, A. (2011). Studies on toxicity of aluminum oxide $\left(\mathrm{Al}_{2} \mathrm{O}_{3}\right)$ nanoparticles to microalgae species: Scenedesmus sp. and Chlorella sp. Journal of Nanoparticle Research, 13(8), 3287-3299. doi: 10.1007/s11051-011-0243-0 
Toksöz A. \& Ustaoğlu M.R. (2005). Gölcük Gölü'nün (Bozdağ, Ödemiş) profoundal makrobentik faunası üzerine araştırmalar (In Turkish with English Abstract). Ege Journal of Fisheries and Aquatic Sciences Cilt/Nolume 22, Sayı//ssue (1-2): 173-175.

Uysal, H., Tuncer S. \& Yaramaz, O. (1987). Gölcük ve Gölmarmara Göllerinde yaşayan $C$. carpio, $S$. glanis, A. anguilla'da bazı ağır metal düzeylerinin araştırıması (In Turkish with English abstract). VIII. Ulusal Biyolof Kongresi, 3-5 Eylül 1986, İzmir, Kongre Kitap̧̧ığı Cilt 2, sayfa 444-453.

Uysal, H., Yaramaz, Ö. \& Tuncer, S. (1985). Gölmarmara ve Gölcük Gölleri'nde fizikokimyasal ve besleyici elementlerin karşılaştırmalı olarak araştııııası (In Turkish with English abstract). Türkiye Tabiatını Koruma Derneğı Yayını 17(1): 157-164.
Üstün, G.E. (2011). The Assessment of heavy metal contamination in the waters of the Nilufer Stream in Bursa. Ekoloji, 20(81), 61-66. doi: 10.5053/ekoloji.2011.819

Yapar, Z. (2015, Temmuz 20). İzmir'de 'pes' dedirten görüntü: 'Cennet'te rezalet.

http://www.egedesonsoz.com/haber/izmir-de-pes-dedirten-goruntucennet-te-rezalet-1903983, retrieved July 29, 2015, (In Turkish).

Yıldız, S., Özbek M., Taşdemir A. \& Topkara, E.T. (2015). Assessment of a Shallow Montane Lentic Ecosystem (Lake Gölcük, Izmir, Turkey) Using Benthic Community Diversity. Ekoloji 24(97), 1-13.

doi: 10.5053/ekoloji.2015.34 